\title{
Survei Geolistrik untuk Pengembangan Irigasi Air Tanah di Kelurahan Lamatti Rilau - Sinjai, Sulawesi Selatan
}

\author{
Muhammad Ramli*, Sufriadin, Aryanti V.A, Irzal Nur, Meinarni Thamrin, Sri Widodo \\ Departemen Teknik Pertambangan, Fakultas Teknik Universitas Hasanuddin \\ ramli@unhas.ac.id*
}

\begin{abstract}
Abstrak
Daerah Lamatti Rilau-Sinjai Utara merupakan daerah dengan bentang alam yang berbukit-bukit. Kondisi bentang alam tersebut menjadi kendala dalam pemenuhan kebutuhan air irigasi pertanian dengan pemanfaatan air permukaan. Oleh karena itu, diperlukan pengembangan air tanah untuk mensuplai kebutuhan air irigasi tersebut sebagai upaya peningkatan produksi. Pengembangan sumber daya air tanah terdiri atas beberapa tahapan, namun hal yang paling mendasar adalah identifikasi keterdapatan air tanah di bawah permukaan. Metode investigasi yang sangat popular adalah pengukuran tahanan jenis batuan. Nilai tahanan jenis batuan merupakan representasi dari variasi karakteristik fisik dan kimia batuan. Oleh karena itu, hubungan antara jenis batuan dan nilai tahanan jenis merupakan dua hal yang menjadi dasar analisis dalam kegiatan ini. Daerah Lamatti Rilau - Sinjai Utara tersusun atas material batuan sedimen Formasi Walanae(Tmpw), Batuan Gunungapi Lompobatang (Qlv) dan Endapan aluvium dan pantai (Qac). Pengamatan lapangan menunjukkan sejumlah singkapan batupasir yang berpotensi sebagai lapisan pembawa air. Nilai tahanan jenis batuan tersebut bervariasi dari 2,0 - 104,0 ohm-m. Variasi nilai tersebut menunjukkan bahwa pada kedalaman tertentu terdapat lapisan pembawa air tanah. Dari 3 titik investigasi geolistrik, titik GL-3 merupakan lokasi yang dapat lakukan pengembangan sumur produksi air tanah dengan kedalaman sumur $100 \mathrm{~m}$.
\end{abstract}

Kata Kunci: Irigasi Air Tanah; Tahanan Jenis; Sumur Produksi; Akifer.

\section{Pendahuluan}

Air tanah merupakan salah satu sumber air untuk mensuplai kebutuhan manusia. Keberadaan air tanah pada lapisan akifer di bawah permukaan menjadi masalah dalam menentukan ketersediaannya dengan pasti. Pengembangan sumber daya air tanah lebih rumit daripada pengembangan air permukaan, karena keterdapatannya tidak dapat dilihat langsung dan besar potensi air tanah tidak dapat diukur secara langsung. Oleh karena itu tahapan kegiatan eksplorasi perlu dilakukan secara berurutan. Berbagai tahapan dan metode investigasi dikembangkan untuk memprediksi hasil kegiatan eksplorasi air tanah yang lebih akurat. Kegiatan eksplorasi meliputi; pemetaan geologi permukaan, penyelidikan geofisika/geolistrik, pemboran pilot hole, dan logging geofisika. Bilamana hasil logging menunjukkan adanya lapisan akifer, maka dilanjutkan dengan tahapan reaming hole (pembesaran lubang bor), konstruksi sumur, dan uji pemompaan, serta uji kualitas air.

Eksplorasi air tanah pada kegiatan ini merupakan pemetaan geologi dan penyelidikan geolistrik. Kegiatan ini merupakan tahap paling awal dalam investigasi kondisi air tanah untuk perencanaan pengembangan potensi air tanah. Dalam kegiatan ini interpretasi keterdapatan air tanah didasarkan pada variasi nilai tahanan jenis dengan jenis batuan penyusun daerah rencana pengembangan irigasi. Rekomendasi dari hasil analisis data-data yang diperoleh dalam kegiatan ini menjadi acuan pada perencanaan kegiatan selanjutnya, yaitu pemboran pilot hole.

Kebutuhan masyarakat akan air irigasi tanah dalam upaya peningkatan produksi pertanian menjadi pertimbangan utama di daerah Lamatti Rilau karena kondisi daerah yang berbukit-bukit. Kelompok Tani Palla Lamatti Rilau telah mengusulkan ke Pemerintah Daerah untuk pengadaan pemboran air tanah. Sehubungan dengan kegiatan pemboran air tanah merupakan tahapan yang 
penting karena berkaitan dengan biaya yang tinggi, maka dilakukan kegiatan Survei Kondisi Air Tanah Dengan Metode Geolistrik. Survei geolistrik merupakan tahapan awal untuk mendapatkan rekomendasi layak atau tidaknya dilakukan pemboran eksplorasi. Survei ini digunakan untuk menjelaskan tentang potensi air bawah tanah guna mendukung pemenuhan kebutuhan air irigasi pertanian.

\section{Teori Dasar}

Metode geofisika dapat digunakan untuk penentuan secara tidak langsung keberadaan dan sifat material geologi di bawah permukaan. Ketebalan material tidak terkonsolidasi, kedalaman muka air tanah, lokasi patahan, dan kedalaman batuan dasar dapat juga ditentukan. Pada beberapa keadaan, lokasi, ketebalan, dan keterdapatan material bawah permukaan, seperti endapan kerikil atau lapisan lempung dapat dievaluasi. Seperti halnya seluruh investigasi hidrogeologi, pendefinisian masalah secara teliti dan penentuan tipe informasi yang perlu diselesaikan seharusnya dibuat sebelum survei geofisika dilaksanakan. Survei geofisika harus direncanakan untuk menghasilkan sejumlah data penting dengan biaya efisien (Fetter, 1988). Survei geoifisika merupakan cara murah untuk meningkatkan pemahaman tentang kondisi geologi. Teknik prospeksi geofisika data menjadi data pelengkap untuk membuat penampang geologi walaupun tidak ada data pemboran. (Rao, et al. 2011).

Metode geofisika permukaan yang paling banyak digunakan untuk investigasi kondisi air tanah adalah Metode Geolistrik khususnya metode tahanan jenis arus searah (Zohdy, Eaton \& Mabey, 1974). Pengukuran dilakukan dengan mengalirkan arus listrik ke dalam tanah dengan menggunakan 2 buah elektroda logam (elektroda arus) yang biasa dikenal sebagai elektroda arus A dan B. Jika tanah kering, di sekitar elektroda perlu disiram air untuk memperbaikan hubungan arus. Tegangan listrik yang terjadi antara dua elektroda juga diukur dengan 2 elektroda logam (elektroda potensial) yang dikenal sebagai elektroda potensial M dan N.

Survei geolistrik umumnya dibedakan atas dua sistem yaitu electrical sounding dan horizontal profiling. Electrical sounding menghasilkan variasi resistivitas semu terhadap kedalaman. Horizontal profiling digunakan untuk menentukan variasi lateral daripada resistivitas. Bilamana spasi elektroda diperbesar pada electrical sounding, jarak antara elektroda potensial dan elektroda arus meningkat. Secara umum, metode geolistrik dilakukan untuk mengukur perubahan tahanan jenis lapisan batuan di bawah permukaan tanah dengan menggunakan 4 buah elektroda yang diatur dengan konfigurasi tertentu. Jenis-jenis konfigurasi elektroda diantaranya: Schlumberger, Wenner, dan Dipole-dipole. Dalam penelitian ini digunakan konfigurasi yang paling umum digunakan untuk electrical sounding adalah Schlumberger.

Pada konfigurasi Schlumberger ini arus (I) diinjeksi ke dalam tanah melalui dua elektroda arus $(\mathrm{AB})$ dan besar beda potensial $(\Delta \mathrm{V})$ yang terjadi akan terekam oleh dua buah elektroda potensial $(\mathrm{MN})$. Susunan elektroda diatur sedemikian rupa sehingga posisi elektroda arus (AB) berada di luar dari pada elektroda potensial (MN). Hubungan antara jarak konfigurasi elektroda (faktor geometri elektroda) dengan nilai tahanan listrik yang terukur menghasilkan nilai tahanan jenis semu $\left(\rho_{\mathrm{a}}\right)$ batuan. Hubungan tersebut dapat ditulis dalam bentuk persamaan berikut ;

$\rho_{\mathrm{s}}=\pi \frac{(\mathrm{AB} / 2)^{2}-(\mathrm{MN} / 2)^{2}}{\mathrm{MN}} \frac{\Delta \mathrm{V}}{\mathrm{I}}$ 
Dimana ; $\rho_{\mathrm{s}}$ adalah tahanan jenis semu (ohm-m), AB adalah panjang bentangan elektroda arus (meter), MN adalah panjang bentangan elektroda potensial (meter), $\mathrm{V}$ adalah beda potensial (mVolt), dan I adalah kuat arus (mA).

Salah tantangan dalam penggunaan metode geolistrik adalah pengakuisisian data dengan adanya noise yang dapat mempengaruhi data yang diperoleh. Noise ini muncul akibat adanya gangguan yang menyebabkan ada data lain yang terekam sehingga sulit mengetahui data asli yang sebenarnya terekam di receiver. Salah satu cara yang bisa dilakukan untuk meminimalisir efek noise tersebut saat akuisisi adalah dengan meningkatkan potensial pada elektroda.

\section{Metode Survei}

Pelaksanaan kegiatan survei air tanah dengan metode geolistrik dilakukan sebanyak 3 titik pengukuran yaitu titik Gl-1, GL-2, dan GL-3 di Kelurahan Lamatti Rilau, Kecamatan Sinjai Utara, Kabupaten Sinjai, Sulawesi Selatan. Peralatan yang digunakan; Peta geologi dan hidrogeologi regional, Peta dasar berupa peta topografi berskala 1 : 50.000, Global Positioning System (GPS), Geolistrik, Elektroda arus (2 buah), Elektroda potensial (2 buah), Kabel roll (4 roll), Hammer (4 buah), Meteran roll (2 buah), Kamera digital, dan Alat tulis serta kalkulator.

Pengukuran geolistrik yang dilakukan bertujuan untuk mendapatkan data sounding terhadap nilai tahanan jenis batuan di bawah permukaan tanah. Tahapan pelaksanaan kegiatan sebagai berikut;

a. Diskusi dengan Pemerintah Daerah Kabupaten Sinjai yang diwaikili oleh Balitbangda Kabupaten Sinjai dan Ketua Kelompok Tani Palla - Kelurahan Lamatti Rilau.

b. Peninjauan lokasi / kawasan persawahan yang menjadi target rencana irigasi air tanah sekaligus memperhatikan kondisi bentang alam yang sesuai dengan syarat-syarat pengukuran geolistrik.

c. Pemetaan geologi tinjau (reconnaisance study) terhadap kondisi geologi daerah rencana pengembangan irigasi air tanah dan sekitarnya untuk mendapatkan gambaran umum tentang kondisi daerah yang meliputi; bentang alam, batuan penyusun, dan struktur geologi.

d. Pengukuran geolistrik pada titik pengukuran yang ditetapkan berdasarkan pertimbangan dapata memenuhi tujuan survei yang didasarkan pada kondisi air tanah keseluruhan daerah survei, pembebasan lahan untuk pemboran, perencanaan irigasi dengan sistem gravitasi.

Teknik pengukuran adalah ;

a. Penentuan letak titik pengukuran sebanyak 3 titik duga yang merupakan titik yang dianggap mewakili seluruh daerah survei.

b. Pengukuran dilakukan dengan menggunakan konfigurasi elektroda Schlumberger dengan panjang bentangan elektroda arus maksimum $300 \mathrm{~m}$ atau AB/2 sebesar 150 meter.

c. Arus yang terinjeksi kedalam tanah terbangkit dari Accu (24 Volt) yang besarnya akan terbaca pada alat geolistrik.

d. Besar beda potensial yang terjadi akan terbaca pada alat geolistrik melalui elektroda potensial MN.

e. Arah bentangan relatif sejajar dengan jurus perlapisan batuan, lurus, dan pada relief yang datar. 


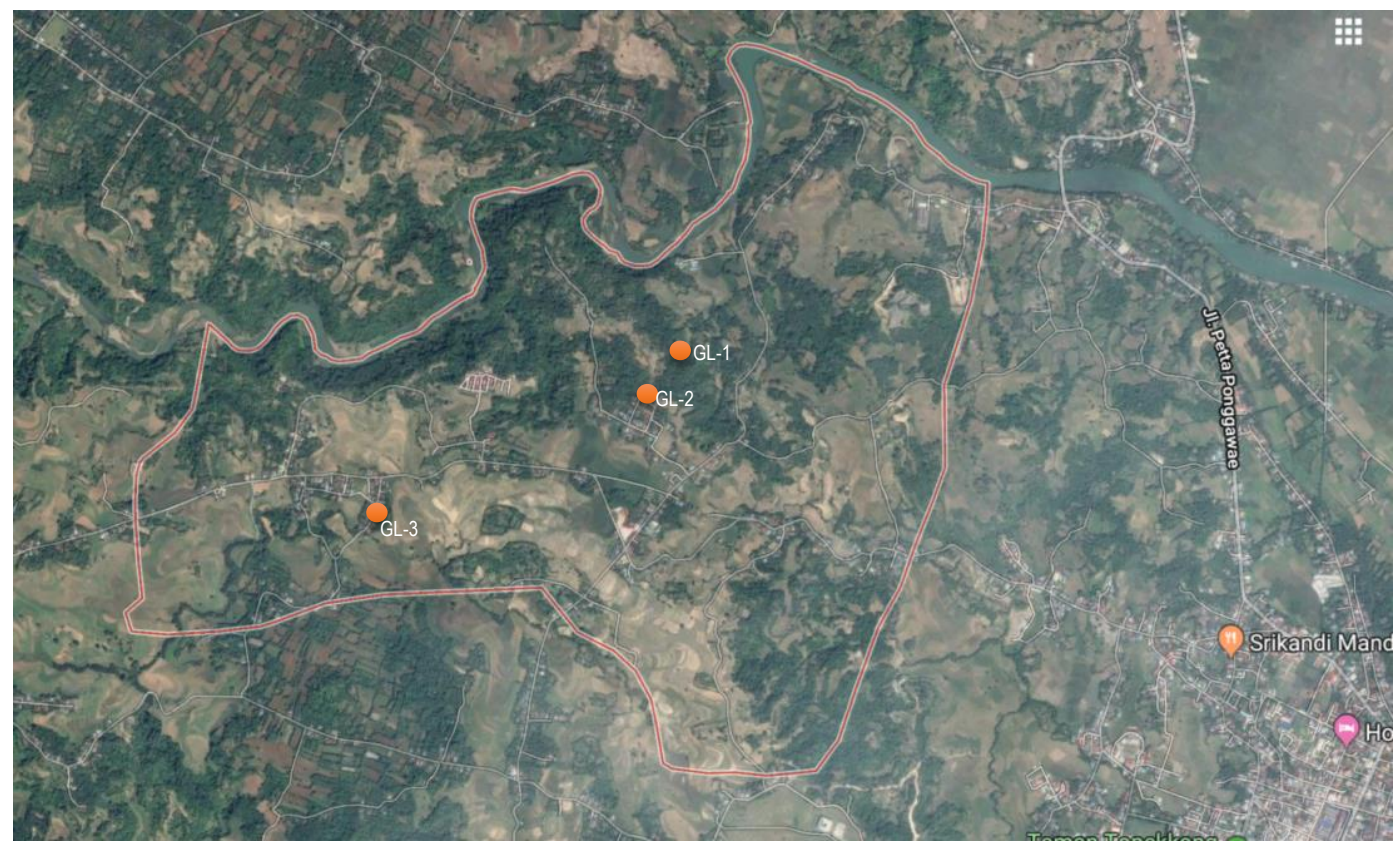

Gambar 1. Posisi Titik Pengukuran Geolistrik

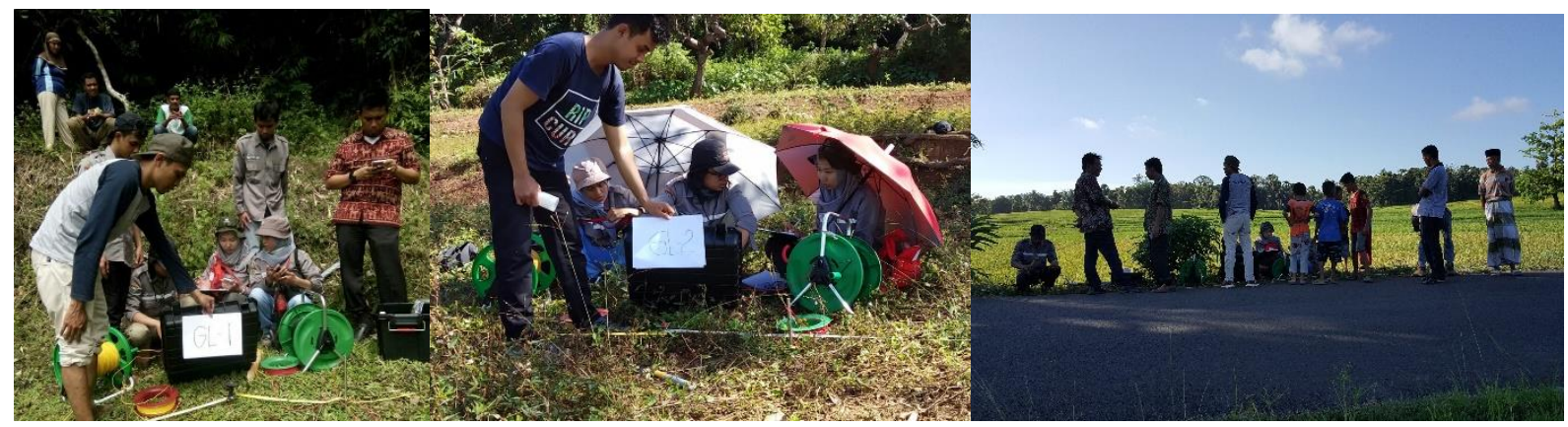

Gambar 2. Foto Kegiatan Pengukuran Geolistrik GL-1, GL-2 \& GL-3

Data hasil pengkuran lapangan selanjutnya dianalisis untuk menjelaskan tentang potensi air tanah di daerah survei. Pengolahan data dan penyusunan laporan merupakan tahapan akhir dari kegiatan survei ini, yang dibagi dalam dua tahapan yaitu;

a. Interpretasi data geolistrik; Data yang diperoleh dari pengukuran lapangan (data electrical sounding) merupakan nilai tahanan jenis semu $\left(\rho_{\mathrm{a}}\right)$. Variasi nilai tahanan jenis semu tersebut kemudian diinterpretasi lebih lanjut untuk mendapatkan nilai tahanan jenis batuan (true resistivity). Dalam pekerjaan digunakan software IP2Win yang diproduksi oleh Moscow State University. Bentuk keluaran ditunjukkan jumlah lapisan tahanan jenis, besar nilai tahanan jenis sebenarnya, ketebalan setiap lapisan, kedalaman setiap lapisan, dan elevasi batas kontak antara lapisan.

b. Penafsiran data geolistrik ke kondisi hidrogeologi; Variasi nilai tahanan jenis batuan tersebut kemudian diintegrasikan dengan kondisi geologi untuk menafsirkan keterdapatan air tanah dalam akifer. Proses penafsiran ini mengacu pada sifat resistensi batuan terhadap aliran arus listrik. Output yang diperoleh pada tahapan ini adalah ;

$\circ$ posisi lapisan pembawa air. 
O ketebalan lapisan pembawa air.

o kualitas air tanah.

- penyebaran lateral lapisan pembawa air.

○ kondisi material di bawah permukaan.

\section{Hasil dan Diskusi}

\subsection{Kondisi Geologi}

MORFOLOGI. Kelurahan Lamatti Rilau merupakan pesisir timur dari Peta Geologi Lembar Ujung Pandang, Benteng, dan Sinjai Sulawesi. Kelurahan Lamatti Rilau merupakan bentang alam perbukitan kecil. Oleh masyarakat setempat dimanfaatkan sebagai lahan persawahan. Sehubungan dengan ketinggian permukaan yang jauh dari permukaan sungai yang ada, maka di daerah ini sangat sulit dilakukan pengembangan irigasi air permukaan.

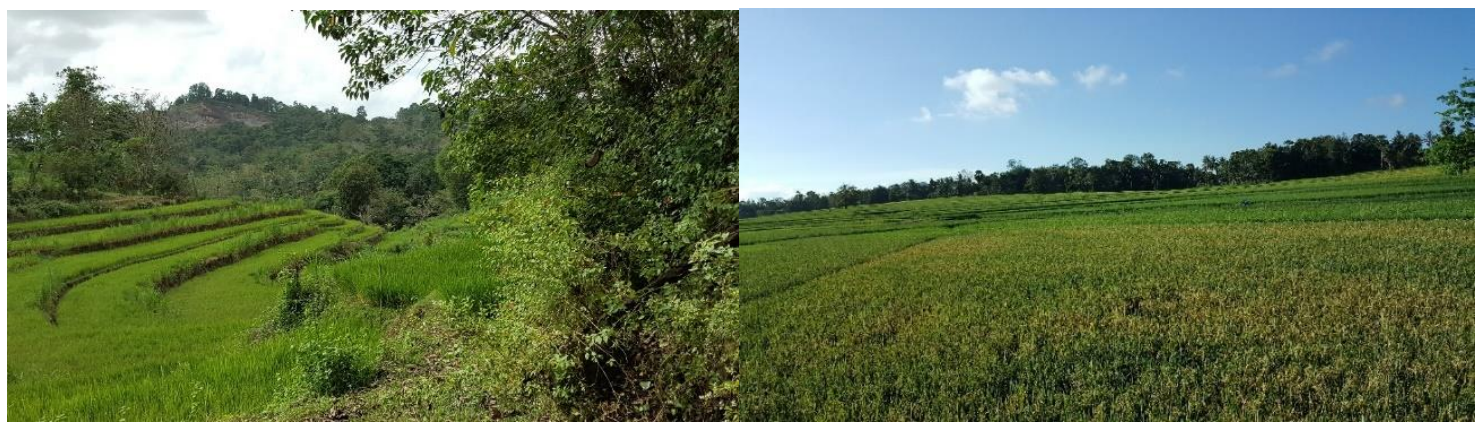

Gambar 3. Foto kenampakan persawahan di lokasi titik GL-1 (kiri) dan GL-3 (kanan).

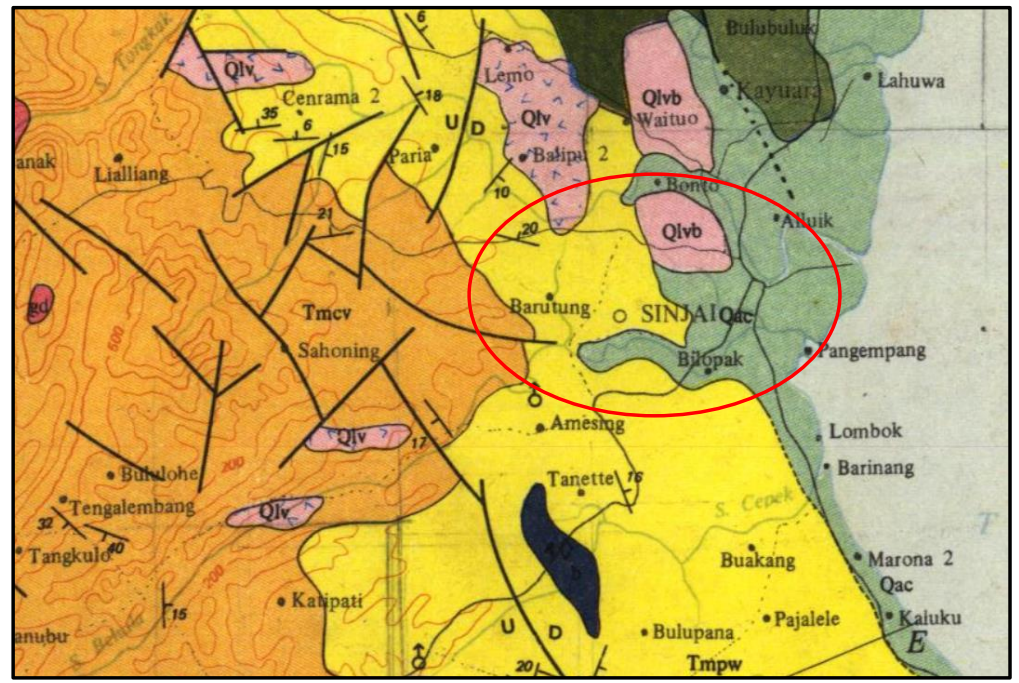

Gambar 4. Peta Geologi Kota Sinjai dan Sekitarnya (modifikasi dari Sukamto, 1982)

LITOLOGI; Kelurahan Lamatti Rilau tersusun atas Formasi Walanae (Tmpw), Batuan Gunungapi Lompobatang (Qlv) dan Endapan aluvium dan pantai (Qac). FORMASI WALANAE tersusun atas perselingan batupasir, konglomerat, dan tufa. dngan sisipan batulanau, batulempung, batugamping, napal dan lignit; Batupasir berbutir sedang sampai kasar, umumnya gampingan dan 
agak kompak, berkomposisi sebagian andesit dan sebagian lainnya banyak mengandung kuarsa; tufanya benkisar dari tufa breksi, tufa lapili dan tufa kristal yang banyak mengandung biotit; konglomerat berkomponen andesit, trakit dan basal, dengan ukuran $1 / 2-70 \mathrm{~cm}$. rata-rata $10 \mathrm{~cm}$. BATUAN GUNUNGAPI LOMPOBATANG : tersusun atas aglomerat, lava. breksi, endapan lahar dan tufa. Batuannya sebagian besar berkomposisi andesit dan sebagian basal, lavanya ada yang berlubang - lubang dan ada yang berlapis; setempat breksi dan tufanya mengandung banyak biotit. ENDAPAN ALUVIUM, RAWA DAN PANTAI (Qac): kerikil. pasir, lempung, lumpur dan batugamping koral. Terbentuk dalam lingkungan sungai. Endapan aluviumnya terutama terdiri dari rombakan batuan gunungapi G. Lompobatang.

STRUKTUR GEOLOGI: Kondisi bentang alam yang merupakan perbukitan rendah yang disertai adanya pelurusan topografi/gawir topografi mengindikasikan adanya patahan di daerah ini. Pada zona patahan tersebut juga ditemukan mata air yang tidak pernah berhenti mengalir sepanjang tahun. Pada zona ini juga ditemukan adanya singkapan lapisan batubara yang terpotong.

\subsection{Kondisi Air Tanah}

Pengukuran geolistrik pada tiga titik duga GL-1, GL-2, dan GL-3 merupakan data sounding (vertical electrical sounding) dimaksudkan untuk mendapatkan variasi nilai tahanan jenis batuan hingga kedalaman 150 meter dari permukaan tanah. Interpretasi kondisi air tanah dilakukan dengan menganalisis variasi data tahanan jenis terukur di lapangan merupakan nilai tahanan jenis semu (apparent resistivity) menjadi nilai tahanan jenis sebenarnya (true resistivity). Nilai true resistivity dijadikan dasar untuk menjelaskan kondisi air tanah dengan pertimbangan bahwa nilai tersebut dipengaruhi oleh jenis batuan penyusun, sifat fluida pengisi pori, karakteristik fisik dan kimia batuan.

\section{TITIK GEOLISTRIK GL-1}

Penafsiran nilai-nilai tahanan jenis tersebut adalah;

a. Lapisan pertama: Lapisan batuan dengan nilai tahanan jenis 7,49 ohm-m yang terdapat pada 0,0 - 0,50 $\mathrm{m}$ di bawah permukaan tanah. Lapisan ini ditafsirkan sebagai lapisan tanah penutup yang merupakan top soil dari pelapukan batuan di bawahnya. Lapisan ini merupakan lapisan tidak jenuh air tetapi memiliki kadar air yang tinggi.

b. Lapisan kedua: Lapisan batuan dengan nilai tahanan jenis 88,90 ohm-m yang terdapat pada kedalaman 0,50 - 1,40 m di bawah permukaan tanah. Lapisan ini ditafsirkan sebagai lapisan batupasir yang tidak mengandung air tanah.

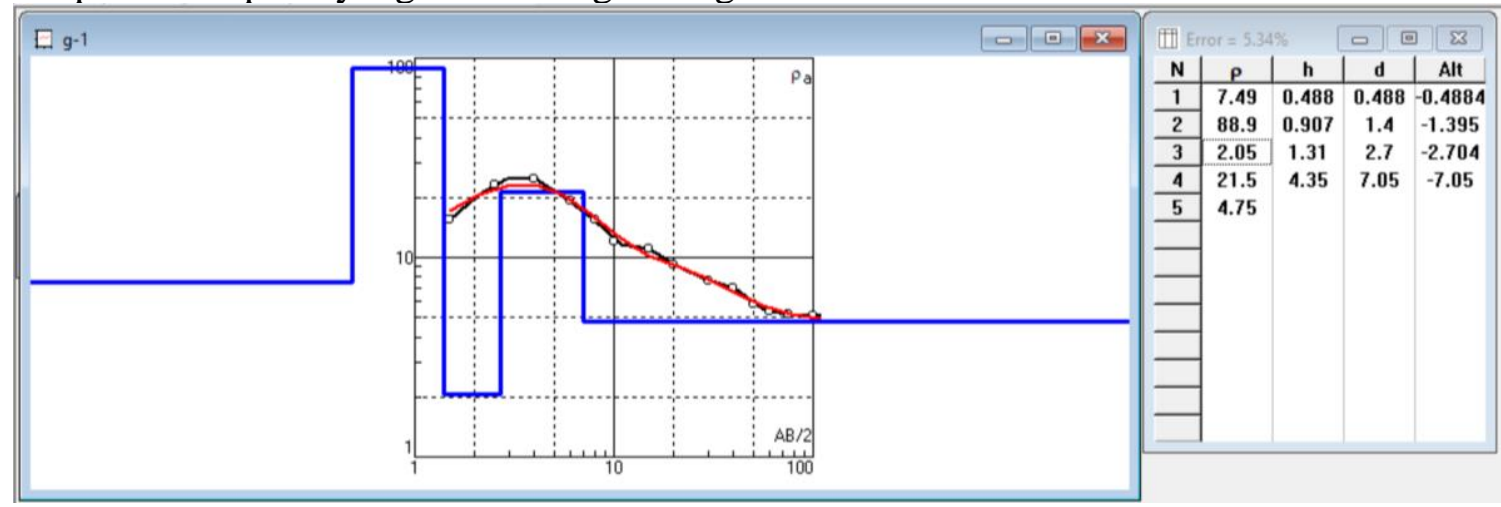

Gambar 5. Hasil interpretasi dengan software IP2Win untuk data G-1 
c. Lapisan ketiga: Lapisan batuan dengan nilai tahanan jenis 2,05 ohm-m yang terdapat pada kedalaman 1,40 - 2,70 m di bawah permukaan tanah. Lapisan ini ditafsirkan sebagai lapisan batupasir lempungan dengan kandungan air tanah yang terbatas.

d. Lapisan keempat: Lapisan batuan dengan nilai tahanan jenis 21,50 ohm-m yang terdapat pada kedalaman 2,70 - 7,00 $\mathrm{m}$ di bawah permukaan tanah. Lapisan ini ditafsirkan sebagai lapisan batulempung dengan kandungan air yang sangat terbatas.

e. Lapisan kelima: Lapisan batuan dengan nilai tahanan jenis 4,75 ohm-m yang terdapat pada kedalaman 7,0 - $100 \mathrm{~m}$ di bawah permukaan tanah. Lapisan ini diperkirakan sebagai lapisan batulempung yang tidak mempunyai kandungan air.

\section{TITIK GEOLISTRIK GL-2}

Penafsiran nilai-nilai tahanan jenis tersebut adalah;

a. Lapisan pertama: Lapisan batuan dengan nilai tahanan jenis 24,00 ohm-m yang terdapat pada 0,0 - 10,50 m di bawah permukaan tanah. Lapisan ini ditafsirkan sebagai lapisan tanah penutup yang merupakan top soil dari pelapukan batuan di bawahnya. Lapisan ini merupakan lapisan tidak jenuh air tetapi memiliki kadar air yang tinggi.

b. Lapisan kedua : Lapisan batuan dengan nilai tahanan jenis 104,00 ohm-m yang terdapat pada kedalaman 1,50 - 3,50 $\mathrm{m}$ di bawah permukaan tanah. Lapisan ini ditafsirkan sebagai lapisan batupasir yang tidak mengandung air tanah.

c. Lapisan ketiga : Lapisan batuan dengan nilai tahanan jenis 2,76 ohm-m yang terdapat pada kedalaman 3,50 - 6,00 m di bawah permukaan tanah. Lapisan ini ditafsirkan sebagai lapisan batulempung dengan kandungan air tanah yang sangat terbatas.

d. Lapisan keempat: Lapisan batuan dengan nilai tahanan jenis 26,10 ohm-m yang terdapat pada kedalaman 6,00 - 11,50 m di bawah permukaan tanah. Lapisan ini ditafsirkan sebagai lapisan batupasir dengan kandungan air yang terbatas.

e. Lapisan kelima: Lapisan batuan dengan nilai tahanan jenis 8,62 ohm-m yang terdapat pada kedalaman 11,50 - $100 \mathrm{~m}$ di bawah permukaan tanah. Lapisan ini diperkirakan sebagai lapisan batupasirlempungan yang mempunyai kandungan air yang terbatas.

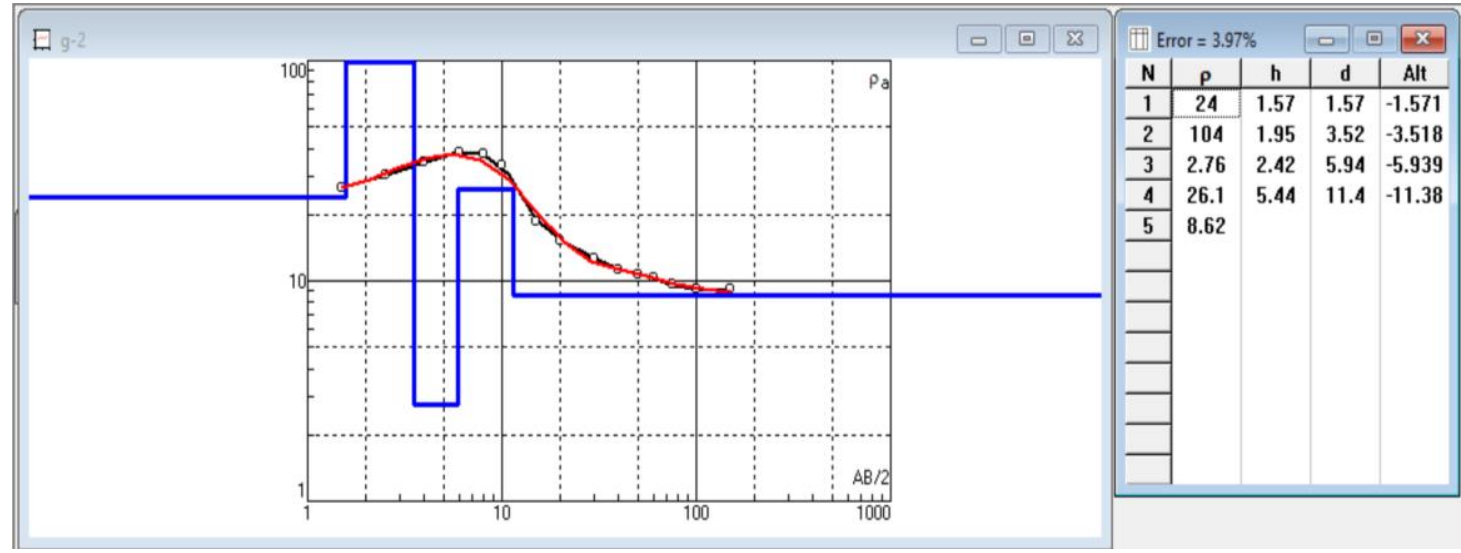

Gambar 6. Hasil interpretasi dengan software IP2Win untuk data G-2

\section{TITIK GEOLISTRIK GL-3}

Penafsiran nilai-nilai tahanan jenis tersebut adalah; 
a. Lapisan pertama: Lapisan batuan dengan nilai tahanan jenis 73,58 ohm-m yang terdapat pada 0,0 - 1,00 $\mathrm{m}$ di bawah permukaan tanah. Lapisan ini ditafsirkan sebagai lapisan tanah penutup yang merupakan tanah timbunan jalan. Lapisan ini tidak memiliki kadungan air tanah.

b. Lapisan kedua : Lapisan batuan dengan nilai tahanan jenis 26,82 ohm-m yang terdapat pada kedalaman 1,00 - 4,00 m di bawah permukaan tanah. Lapisan ini ditafsirkan sebagai lapisan batupasir yang mengandung air tanah terbatas.

c. Lapisan ketiga: Lapisan batuan dengan nilai tahanan jenis 11,84 ohm-m yang terdapat pada kedalaman 4,00 - 8,00 m di bawah permukaan tanah. Lapisan ini ditafsirkan sebagai lapisan batupasir dengan kandungan air tanah.

d. Lapisan keempat : Lapisan batuan dengan nilai tahanan jenis $26,84 \mathrm{ohm}-\mathrm{m}$ yang terdapat pada kedalaman 8,00 -17,00 m di bawah permukaan tanah. Lapisan ini ditafsirkan sebagai lapisan batupasir yang mengandung air tanah.

e. Lapisan kelima: Lapisan batuan dengan nilai tahanan jenis 4,85 ohm-m yang terdapat pada kedalaman 17,00 - 36,00 m di bawah permukaan tanah. Lapisan ini ditafsirkan sebagai lapisan batulempung dengan kandungan air yang sangat terbatas.

f. Lapisan keenam: Lapisan batuan dengan nilai tahanan jenis 10,77 ohm-m yang terdapat pada kedalaman 36 - 100 m di bawah permukaan tanah. Lapisan ini diperkirakan sebagai lapisan batupasir yang mempunyai kandungan air yang banyak.

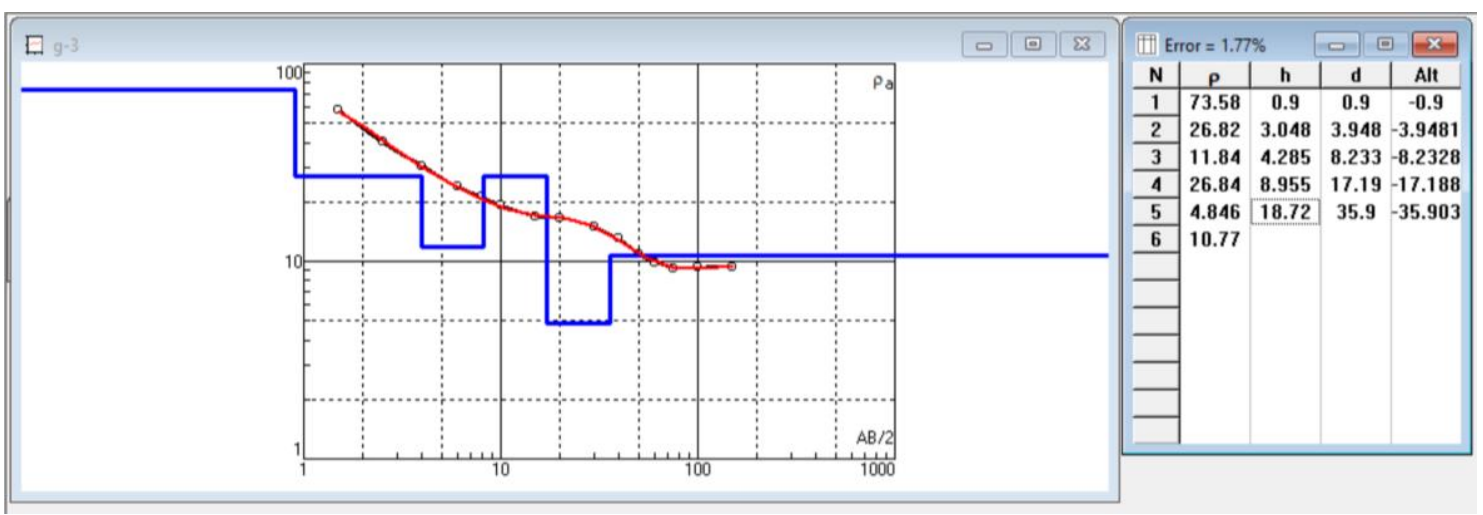

Gambar 7. Hasil interpretasi dengan software IP2Win untuk data G-3

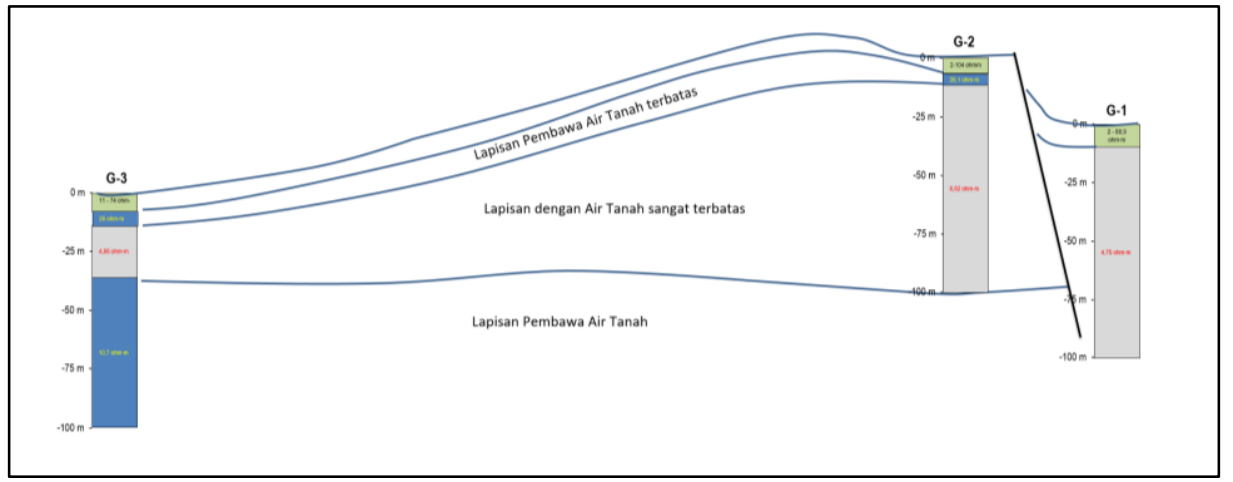

Gambar 8. Panampang hidrogeologi di Lamatti Rilau - Sinjai.

Berdasarkan atas hasil penafsiran kondisi air tanah dari hasil pengukuran tiga titik geolistrik, maka diperoleh penampang hidrogeologi pada Gambar 8. Dari tiga titik duga yang diukur hanya pada titik GL-3 yang memungkinkan untuk dilanjutkan untuk kegiatan pemboran eksplorasi. Dua titik 
geolistrik lainnya, GL-1 dan GL-2, tidak memiliki potensi air tanah. Hal tersebut kemungkinan dipengaruhi oleh struktur patahan yang ada di sekitarnya, sehingga lapisan batuan yang dapat bersifat sebagai akifer tidak dapat dimanfaat sebagai lapisan pembawa air yang potensial untuk pemboran eksplorasi. Selanjutnya pada titik geolistrik GL-3 dibuat rencana umum untuk pembuatan sumur eksplorasi. Rencana konstruksi yang detail dan akurat akan diperoleh setelah kegiatan pemboran pilot hole dan logging geofisika pada tahapan kegaitan berikutnya.

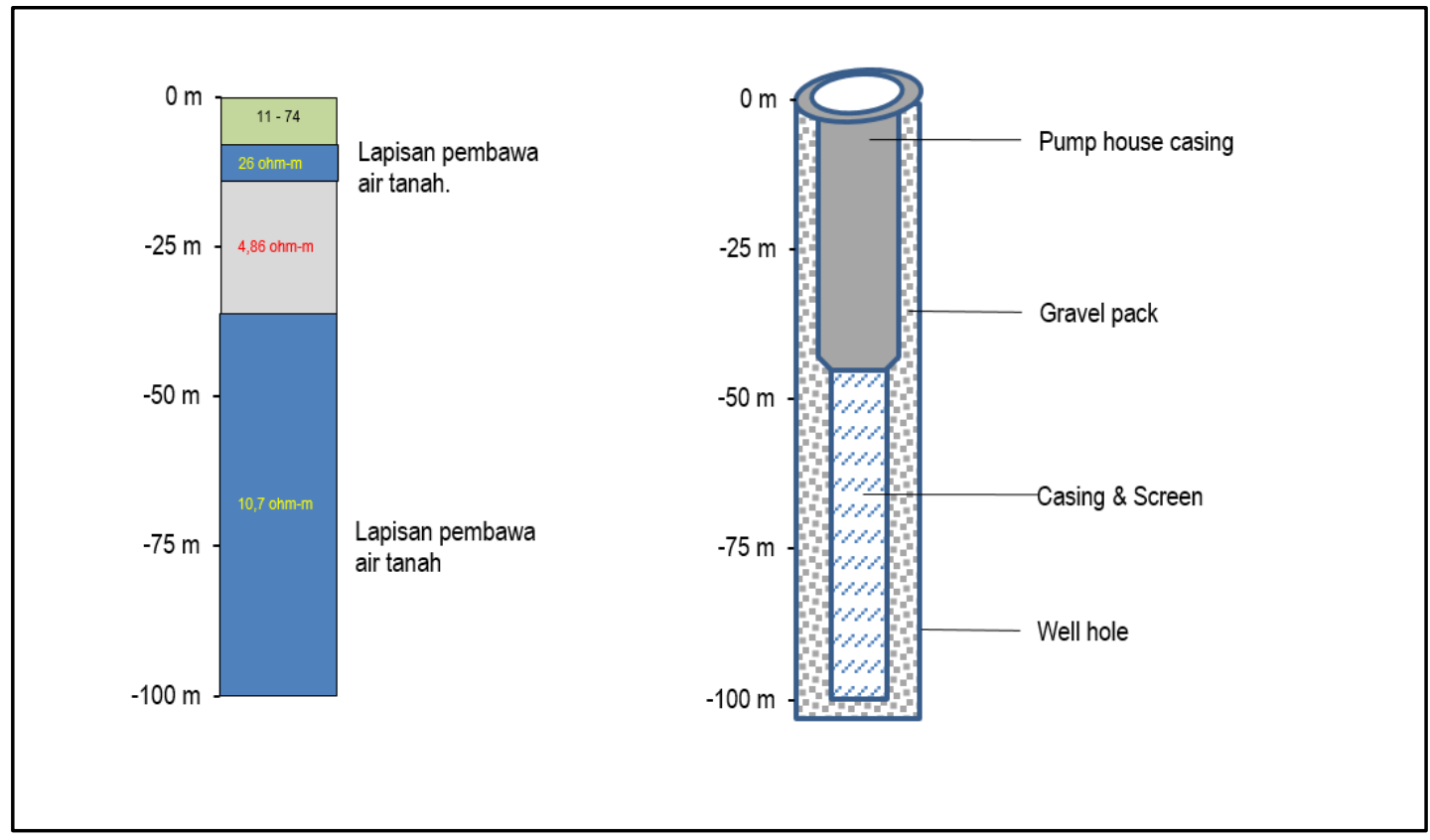

Gambar 9. Gambaran umum tentang kondisi titik G-3 dan rencana umum sumur produksi air tanah.

\section{Kesimpulan}

Berdasarkan hasil interpretasi titik-titik sounding geolistrik, maka kondisi air tanah di daerah Lamatti Rilau dapat direkomendasikan sebagai berikut;

a. Titik Geolistrik GL-1 dan GL-2 tidak ditemukan lapisan batuan pembawa air tanah yang berpotensi untuk dikembangkan menjadi sumur produksi air tanah. Kawasan ini juga dipengaruhi oleh keberadaan sesar normal.

b. Titik Geolistrik GL-3 memiliki lapisan batuan pembawa air tanah pada kedalaman 40,00 100 meter, dengan produktifitas sedang. Pemboran ekplorasi untuk pengembangan sumur produksi air tanah direkomendasikan hingga kedalaman 100 meter.

\section{Ucapan Terima Kasih}

Ucapan terima kasih disampaikan kepada Lembaga Penelitian dan Pengabdian Masyarakat Universitas Hasanuddin atas dukungan dana kegiatan. Terima kasih juga kami sampaikan ke pihak Kantor Balitbangda Sinjai dan Kelompok Tani Palla atas dukungannya selama pelaksanaan kegiatan. 


\section{Daftar Pustaka}

Fetter C.W., (1988). Applied Hydrogeologi, Third Edition, Prentice-Hall Inc, Englewood Cliffs. Moscow State University Geological Faculty Department of Geophysics 2001. WIN with IPI2Win Geoscan-M Ltd. Moscow.

Rao VVSG, Rao GT, Surinaidu L, Rajesh R, and Mahesh J., (2011). Geophysical and Geochemical Approach for Seawater Intrusion Assessment in the Godavari Delta Basin, A.P. India Water Air Soil Pollution. Vol. 217, pp. 503-514.

Sukamto, R., (1982), Peta Geologi Lembar Pangkajene dan Watampone Bagian Barat, Sulawesi, Pusat Penelitian dan Pengembangan Geologi, Bandung.

Zohdy, A.A.R., Eaton, G.P., and Mabey, D.R., (1974). Application of Surface Geophysics to Ground Water Investigation, Techniques of Water Resources Investigation of the United States Geological Survey, United States Government Printing Office, Washington. 